\title{
Monitoring of the Dissemination of Salmonella in the Chicken Frankfurt-sausage Production Line of a Sausage Factory in the State of São Paulo, Brazil
}

\author{
Alexandre de Freitas Luiz/*, Fabiana Campiteli Moreira, Edinéia de Fátima Corrêa, \\ Deise Pasetto Falcão/ ${ }^{+}$
}

\begin{abstract}
Departamento de Ciências Biológicas, Faculdade de Ciências Farmacêuticas, Unesp, Rodovia Araraquara-Jaú km 1, 14801-902 Araraquara, SP, Brasil *Departamento de Pesquisas, Faculdade de Ciências Agrárias, Unicastelo, Campus VIII, Descalvado, SP, Brasil
\end{abstract}

Poultry meat and its derivatives are among the foodstuffs considered by environmental health authorities to present the highest risks to the public. A total of 185 samples were collected in five monthly batches, from different processing stages in a sausage plant that uses mechanically-deboned chicken meat (MDCM), and tested for the presence of Salmonella. Enrichment was carried out in both Kauffman's tetrathionate broth and Rappaport-Vassiliadis broth and isolation on Salmonella-Shigella agar and brilliant-green agar. Live Salmonella bacteria were isolated from six samples of the raw meat and from the emulsion, in batches three, four, and five, but not from any sample in batches one or two. The six isolated strains were all classified as Salmonella Albany, which has not previously been reported in MDCM. Of the two enrichment broths, Rappaport-Vassiliadis gave the better results. The pattern of contamination suggests a probable common source, given that a new supplier was used in the third, fourth, and fifth months. It was also shown that the industrial cooking was effective in preventing Salmonella surviving in the final product.

Key words: Salmonella - chicken Frankfurt-sausage - mechanically-deboned chicken meat (MDCM) - industrial monitoring

Poultry meat and its derivatives are among the foodproducts that cause the most concern to Public Health authorities, owing to the associated risks of bacterial foodpoisoning (Baeumler et al. 2000, Beli et al. 2001).

The growing commercialization of fowl-rearing has enabled a great variety of products to be offered: whole chicken, pastries, sausages, etc. The process of mechanical deboning has made the removal of all the meat left on the carcass, neck, and back of the chicken commercially viable, thus providing a new raw material for processed meat products: mechanically-deboned chicken meat (MDCM) (Beraquet et.al. 1992, Souza et al. 2003).

Frankfurt sausages are consumed worldwide. They are made from an emulsion of meat, fat, and condiments, although the exact ingredients vary widely, depending on the tradition of each sausage-maker and local custom. Mechanically-deboned meat, and in particular MDCM, has become a common ingredient of the 'frankfurter', mainly due to its low price (Beraquet et al. 1992).

Salmonella is one of the microorganisms most frequently associated with outbreaks of illness spread by food. Meat in general and poultry in particular are the commonest source of food-poisoning by Salmonella (Hoffer et al. 1997, D’ Aoust, 1997, Antunes et al. 2003). According to current legislation (Brasil 2000, 2001), meat

${ }^{+}$Corresponding author. Fax: +55-16-3301.6940. E-mail: falcaodp@fcfar.unesp.br

Received 6 February 2004

Accepted 30 June 2004 and meat derivatives, including cooked meat products, must have no living Salmonella cells in a $25 \mathrm{~g}$ sample.

In the same geographic area as the current study, previous investigations of food products have demonstrated the presence of Salmonella, but only in the final product, there being no information on contamination of the original material and/or the production line (Falcão et al.1978, Leite et al. 1988, Falcão et al. 2002).

The current study was carried out in a sausage factory in the state of São Paulo, Brazil, where MDCM is the raw material used to produce chicken Frankfurt-sausages (uncured, cooked). The factory had no system of microbiological control of the end product, the raw material or the other ingredients, at any stage of production. The aim was to evaluate the microbiological purity of the product and to monitor the entire chicken Frankfurt-sausage production line.

\section{MATERIALS AND METHODS}

Chicken Frankfurt-sausage processing - The raw material for the chicken sausages was MDCM, obtained from two different abattoirs. The MDCM was delivered wrapped and frozen in blocks of about $20 \mathrm{~kg}$, which were stored at $-12^{\circ} \mathrm{C}$ (Figure). The frozen block was unwrapped, broken into smaller chunks, and transferred to the chopping machine, where was homogenized with the other ingredients (water, texturized soy protein, cassava starch, condiments, preservatives, emulsifiers, and antioxidants). The resulting batter or emulsion was fed through a stuffing horn into artificial casings, made of a polyamide. The filled casings were cooked for $1 \mathrm{~h}$ at $90^{\circ} \mathrm{C}$. The emerging Frankfurt-sausages were cooled by spraying with water, peeled, and then dyed. Dyeing consisted of immersion in 
an $11 \%$ solution of a natural dye (urucum) for $1 \mathrm{~min}$, and then dipping for 5-6 s in a tank containing $0.75 \%$ phosphoric acid. The finished Frankfurt-sausages were left to dry in a storage cooler $\left(3^{\circ} \mathrm{C}\right.$ to $\left.5^{\circ} \mathrm{C}\right)$ for at least $3 \mathrm{~h}$, and then wrapped in polythene sheet, heat-sealed, subjected to the Cry-o-Vac process, and boxed. The boxes were shipped to retailers or kept in a refrigerated store $\left(0^{\circ} \mathrm{C}\right.$ to $5^{\circ} \mathrm{C}$ ) until shipment.

Sampling - A total of 185 samples were collected for analysis, at various points in the chicken-sausage production line (Figure). Sampling was carried out once a month over five months.

Samples of MDCM (M), after removing the wrapping $\left(\mathrm{M}_{1}\right)$ and after leaving the block-breaker $\left(\mathrm{M}_{2}\right)$; condiment mixture $(\mathrm{C})$; emulsion $(\mathrm{Em})$; filled casing $(\mathrm{F})$, and Frankfurt-sausages $(S)$, after cooking $\left(S_{1}\right)$, after dyeing $\left(S_{2}\right)$, before packing $\left(S_{3}\right)$, and from the final product $\left(S_{4}\right)$, were

ARRIVAL OF RAW MATERIAL

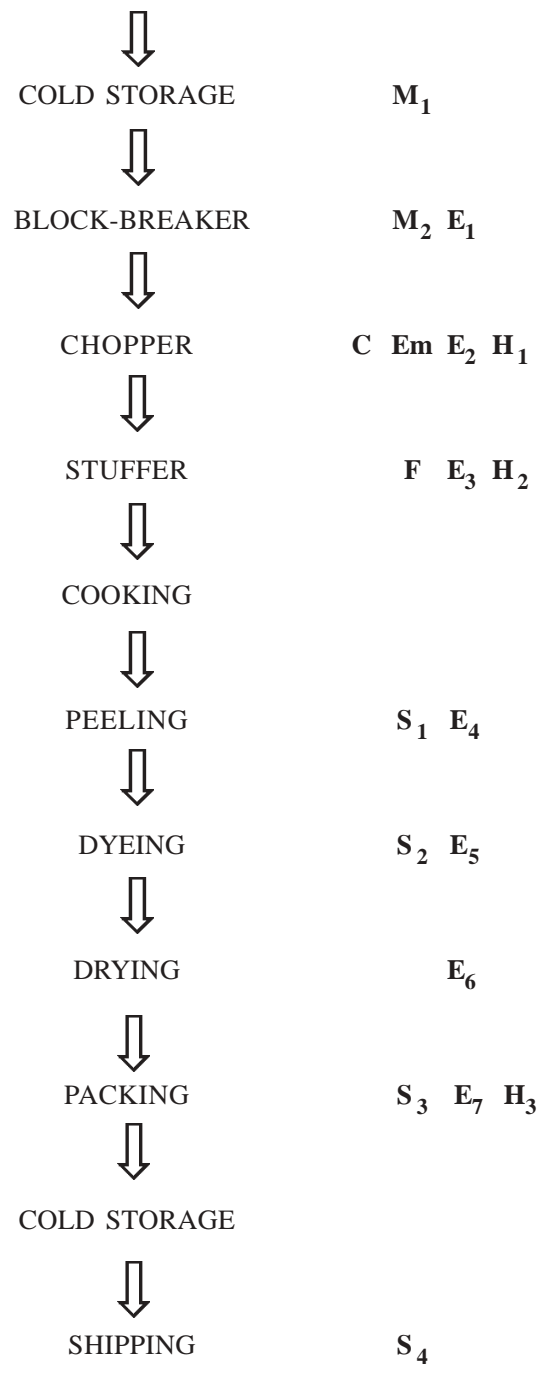

Diagram of chicken Frankfurt-sausage production line, indicating sampling points for mechanically-deboned chicken meat $\left(\mathrm{M}_{1}\right.$ and $\mathrm{M}_{2}$ ), equipment and utensil surfaces (E), condiment mixture (C), emulsion (Em), hand-washings of workers $(\mathrm{H})$, filled casings $(\mathrm{F})$, finished Frankfurt-sausages (S) taken in triplicate ( $100 \mathrm{~g}$ each) making a total of 135 samples.

Surfaces of equipment and utensils (E), were sampled at seven collection points, a total of 35 samples being taken: from the surface of the block-breaker before the start of processing $\left(\mathrm{E}_{1}\right)$; from the blade of the chopper $\left(E_{2}\right)$; from the external $\left(E_{3}\right)$, and internal $\left(E_{4}\right)$ parts of the Frankfurt-sausage stuffing and skinning machines, respectively; from the plastic boxes in which the Frankfurt-sausages were placed, soon after dyeing $\left(\mathrm{E}_{5}\right)$; from the surface of the stockroom $\left(\mathrm{E}_{6}\right)$, and on the surface of the packing table $\left(E_{7}\right)$. Surface samples were collected by wiping the chosen spots with sterilized swabs, previously humidified with $0.85 \%$ saline solution. At each point, three sub-samples were transferred to a single test-tube containing $10 \mathrm{ml}$ of sterile $0.85 \%$ saline, so that one sample was obtained.

Hands of operatives $(H)$ - A total of 15 samples were taken from washed hands of three workers: $\mathrm{H}_{1}$ from the worker who prepared the emulsion in the chopper, $\mathrm{H}_{2}$ from the operator of the casing stuffer, and $\mathrm{H}_{3}$ from one of the manual packers. Each worker washed one hand for about $60 \mathrm{~s}$ in $100 \mathrm{ml}$ of sterile $0.85 \%$ saline solution.

After collection, the samples were placed in sterile plastic boxes with ice, transported to the laboratory and tested.

Analysis - $25 \mathrm{~g}$ of each of the samples of MDCM, emulsion, stuffed casing, cooked Frankfurt-sausages, and condiment mixture was weighed and a $25 \mathrm{ml}$ portion measured from each of the hand-wash samples. In the case of the surface swabbings, the whole $10 \mathrm{ml}$ sample was used. All these sample portions were homogenized aseptically in $225 \mathrm{ml}$ of buffered peptone water (BPW), and incubated for $24 \mathrm{~h}$ at $35-37^{\circ} \mathrm{C}$ as a pre-enrichment step (ICMSF 1988). One $\mathrm{ml}$ and $0.1 \mathrm{ml}$ aliquots of the incubated BPW were used to seed Kauffman's tetrathionate, TT (Difco), and Rappaport-Vassiliadis, RV (Vassiliadis 1983), enrichment broths, which were incubated for $24 \mathrm{~h}$ at $37^{\circ} \mathrm{C}$ and $42^{\circ} \mathrm{C}$, respectively. Isolation were performed on brilliantgreen, BG (Difco), and Salmonella-Shigella, SS (Difco), agars. BPW were also streaked directly on MacConkey (MC) agar (Difco). All agar plates were incubated at $37^{\circ} \mathrm{C}$ for $24 \mathrm{~h}$ and then read. Suspect colonies were tested biochemically and serologically for somatic and flagellar antigens (Ewing 1986) using antisera from Probac do Brasil Produtos Ltda., Brazil. The complete serotyping was carried out at the Adolfo Lutz Institute, São Paulo, Brazil.

\section{RESULTS}

In the analyses carried out on the 185 samples taken from the chicken Frankfurt-sausage production line, Salmonella strains were found in four of the 30 samples of MDCM (13.33\%) and in two of the 15 samples of emulsion (13.33\%), making a total of six positive isolates in the 185 samples examined (3.24\%). No Salmonella was isolated from emulsion in filled casings, operatives hands, swabbed surfaces, condiment mixture or cooked Frankfurt-sausages.

The strains were isolated only from the third, fourth, and fifth sampling batches. In the third batch, Salmonella were isolated from one of the samples of frozen MDCM, taken after the block-breaking step $\left(\mathrm{M}_{2.3}\right)$, while in the fourth, they were also found in frozen MDCM, but in a 
sample taken before the block had been broken $\left(\mathrm{M}_{1.1}\right)$. In the fifth and last batch, Salmonella was found in two samples of frozen MDCM, one taken before $\left(\mathrm{M}_{1.1}\right)$ and one after $\left(\mathrm{M}_{2.1}\right)$ the block-breaking step, and also in two samples of emulsion, before it was poured into the polyamide casings $\left(\mathrm{Em}_{1.2}\right.$ and $\left.\mathrm{Em}_{1.3}\right)$.(Table)

The six Salmonella strains were isolated on both SS and BG agars, after enrichment in Rappaport-Vassiliadis broth. No Salmonella was found after enrichment on Kauffman's tetrathionate broth or after direct isolation on MacConkey agar (Table).

Serological analysis classified the Salmonella strains as $S$. Albany.

\section{DISCUSSION}

Good microbiological quality control at every stage of industrial Frankfurt-sausage-making, especially when the meat used is poultry, is a deciding factor in the quality, shelf-life and acceptability of the product to the consumer, who demands ever higher standards. Salmonella contamination at any step of the process normally renders the sale of the product impossible, as a result of the threat of food-poisoning.

In three of the five sampling batches made during the investigation, $S$. Albany bacteria were isolated from four samples of frozen MDCM and, in one of these batches, the contamination persisted up to the emulsion stage. These results indicate a raw material unsuitable for use in encased emulsion meat products (sausages). The contamination of two samples of emulsion shows that Salmonella was able to survive after the addition of preservatives, a fact that could signify a serious risk in the final product.

On the four occasions when Salmonella was isolated from MDCM, the microorganisms were never found in more than one of the three samples taken from a given source, whereas in the case of the emulsion, the bacteria were isolated from two out of three samples examined. This demonstrates the importance of analyzing a large number of samples of the same material.
$S$. Albany is a serovar that is infrequently reported in isolates related to infection, whether animal or human (D’Aoust 1997). This serovar has been identified in chicken carcass (Rigby et al. 1982, Peresi et al. 1997) but to the best of our knowledge, this is the first recorded account of its isolation from MDCM.

The Salmonella contamination in the MDCM was encountered only in the third, fourth, and fifth batches of samples. This may be explained by the origin of the MDCM. There was a change of supplier of this raw material in the course of the experiment. During the first two months of collection, the MDCM came from a poultry slaughterhouse, whereas on the last three occasions, the supplier was a different slaughterhouse in another part of the State of São Paulo. Both were subject to federal inspection.

Salmonella was not isolated from any of the samples of cooked Frankfurt-sausage, including those made from contaminated MDCM and emulsion. This demonstrates that, for the material examined, the industrial cooking process was adequate for the elimination of Salmonella contamination from the final product.

Another aspect of our experiments is worth commenting on: the evaluation of the enrichment and isolation media used. All the strains isolated had been enriched in RV broth and streaked on SS and BG agars. None strain of Salmonella was isolated after enrichment in TT broth, showing that RV broth was the more effective enrichment medium under these conditions. These data confirm those of other authors who have reported the superiority of RV broth for the isolation of Salmonella (Falcão \& Suassuna 1971, Kalopothaki et al. 1983, Pereira et al. 1989, Gelli et al. 1989, Maijala et al. 1992). Moreover, direct streaking of homogenized samples on MC agar did not lead to any Salmonella isolates at all.

In a general way, the hygiene and sanitary conditions observed in the sausage plant during the experimental period were not very satisfactory. Besides Salmonella, a large number of other Gram-negative spoilage bacteria were found (data not shown). Two facts called our attention: the disinfection of machines and utensils after use was

TABLE

Distribution of the six isolates of Salmonella Albany, with respect to collecting batch, sample, source of sample, and isolation method

\begin{tabular}{|c|c|c|c|c|c|}
\hline \multirow[b]{2}{*}{ Batch nr } & \multirow[b]{2}{*}{ Sample } & \multirow[b]{2}{*}{ Source of sample } & \multicolumn{3}{|c|}{ Isolation method } \\
\hline & & & Direct streakingon $\mathrm{MC}$ & $\mathrm{TT} 37^{\circ} \mathrm{C}$ & $\mathrm{RV} 43^{\circ} \mathrm{C}$ \\
\hline 3 & $\mathrm{M}_{2.3}$ & MDCM broken & - & - & BG, SS \\
\hline 4 & $\mathrm{M}_{1.1}$ & MDCM block & - & - & BG, SS \\
\hline 5 & $\mathrm{M}_{1.1}$ & MDCM block & - & - & BG, SS \\
\hline 5 & $\mathrm{M}_{2.1}$ & MDCM broken & - & - & BG, SS \\
\hline 5 & $\mathrm{Em}_{1.2}$ & Emulsion & - & - & BG, SS \\
\hline 5 & $\mathrm{Em}_{1.3}$ & Emulsion & - & - & BG, SS \\
\hline
\end{tabular}

MC: MacConkey agar; TT: Kauffman's tetrathionate broth; RV: Rappaport-Vassiliadis broth; BG: brilliant green agar; SS: SalmonellaShigella agar; MDCM: mechanically-deboned chicken meat 
nothing more than washing with water jets to remove residues, and the finished sausages were handled and laid on the wrapping sheet by workers using their bare hands.

After receiving the results of this research, the owners of the plant showed much interest in improving the quality of production and therefore of the end product, particularly in relation to its shelf-life, since a considerable number of the sausages delivered to retailers were spoiled before the recommended sell-by date, incurring large financial losses.

Currently, the sanitizing of equipment and utensils consists of a preliminary rinse with jets of water, manual scrubbing with a specific type of fiber and then washing with disinfectants. These practices were installed after the factory contracted a veterinary sanitarist who was put in charge of quality control in the plant and made responsible for supervising the stages of production. Finally, the handling of products, at all stages, is now only carried out by someone wearing the gloves specified for the operation.

This plant is now monitored by the Brazilian Federal Inspectorate, permitting the sale of the product throughout Brazil.

Hence, this investigation made a valuable contribution to the industry and to the public, revealing the source of contamination (the raw material) and highlighting the critical step for the elimination of Salmonella (industrial cooking). These data gave the plant the means to introduce an effective control system to prevent contamination, resulting in a higher quality product with a longer shelf-life. The lower level of consumer risk implied greater success in the market.

\section{REFERENCES}

Antunes P, Réu C, Sousa JC, Peixe L, Pestana, N 2003. Incidence of Salmonella poultry and their susceptibility to microbial agents. Int J Food Microbiol 82: 97-103.

Baeumler AJ, Hargis BM, Tsolis RM 2000. Tracing the origins of Salmonella outbreaks. Science 287: 50-52.

Beli E, Duraku E, Telo A 2001. Salmonella serotypes isolated from chicken meat in Albania. Int J Food Microbiol 71: 263266.

Beraquet NJ, Galvão MTEL, Silva RZM, Arima HK 1992. Efeito das condições de processamento e rendimento e na composição de carne de frango mecanicamente separada de dorso sem pele. Colet ITAL, Campinas, 22: 137-144.

Brasil 2000. Instrução Normativa no. 4. Regulamento Técnico para Fixação de Identidade e Qualidade de Carne Mecanicamente Separada (CMS) de Aves, Bovinos e Suínos, Secretaria de Defesa Agropecuária, Ministério da Agricultura e Abastecimento, Brasília.

Brasil 2001. Resolução RDC no. 12. Regulamento Técnico de Padrões Microbiológicos para Alimentos, Agência Nacional de Vigilância Sanitária, Ministério da Saúde, Brasília.

D'Aoust JY 1997. Salmonella species. In MP Doyle, LR Beuchat, TJ Montville (eds), Food Microbiology Funda- ments and Frontiers, ASM Press, Washington, DC, p. 129158.

Ewing WH 1986. Edwards and Ewing's Identification of Enterobacteriaceae, 4 th ed., Elsevier, New York, 536 pp.

Falcão DP, Suassuna I 1971. Comparação do meio de Rappaport e do meio de Tetrationato de Kauffman, em diversos esquemas para isolamento de Salmonella. Isolamento eventual de Shigella. Rev Microbiol 2: 29-36.

Falcão DP, Lopes MA, Bussadori NM, Oda AH, Oliveira AG, Pimentel EP, Rossi EA 1978. Microrganismos em alimentos cárneos crus embutidos. Rev Fac Ciênc Farm Araraquara 1: 39-48.

Falcão JP, Dias AMG, Corrêa EF, Falcão DP 2002. Microbiological quality of ice used to refrigerate foods. Food Microbiol 19: 269-276.

Gelli DS, Pardini PM, Menicucci S, Lima MC 1989. Salmonelas em carnes frescas e embutidos. Incidência e meios de cultura para o seu isolamento. In Congresso Brasileiro de Microbiologia, 15, Ribeirão Preto, SP, Anais, p. 39.

Hofer E, Silva Filho SJ, Reis EMF 1997. Prevalência de sorovares de Salmonella isolados de aves no Brasil. Pesq Vet Bras 17: 55-62.

ICMSF-International Commission on Microbiological Specifications for Foods 1988. Microorganisms in Foods 1: Their significance and Methods of Enumeration, 2nd ed., University of Toronto, Canada, $434 \mathrm{pp}$.

Kalapothaky V, Vassiliadis P, Mavromati C, Trichopoulos D 1983. Comparison of Rappaport-Vassiliadis enrichment medium and tetrathionate brilliant green broth for isolation of Salmonella from meat products. J Food Protect 46: 628631.

Leite CQF, Valentini SR, Falcão DP 1988. Pesquisa de enteropatógenos em alimentos cárneos crús. Ciênc Tecnol Aliment 8: 155-168.

Maijala R, Johanson T, Hirn J 1992 Growth of Salmonella and competing flora in five commercial Rappaport-Vassiliadis (RV) media. Int J Food Microbiol 7: 1-8.

Pereira ML, Carmo LS, Vieira MBCM, Silva MCC, Souza JM 1989. Presença de Salmonella em lingüiça frescal. Influência da metodologia de pesquisa e avaliação da antibióticoresistência do microrganismo. Ciênc Tecno Aliment 9: 115137

Peresi JTM, Almeida IAZC, Lima SI, Fernandes SA, Gorayeb TCC 1997. Incidência de Salmonella em carcaças de frango comercializadas na região de São José do Rio Preto. In Congresso Brasileiro de Microbiologia, 29, Rio de Janeiro, Anais, p. 279.

Rigby CE, Pettit AH, Bentley JL, Spencer MO, Salomons MO, Lior H 1982. The relationships of Salmonellae from infected broiler flocks, transport crates or processing plants to contamination of eviscerated carcasses. Can J Comp Med 46: 272-278.

Sousa EA, Teixeira LCV, Mello MRPA, Torres EAFS, Moita Neto JM 2003. Aplicação de redes neurais para avaliação do teor de carne mecanicamente separada em salsicha de frango. Ciên Tecnol Aliment 23: 307-311.

Vassiliadis P 1983. The Rappaport-Vassiliadis (RV) enrichment medium for the isolation of Salmonellae: an overview. $J$ Appl Bacteriol 54: 69-76. 